\title{
Phytotoxic effect of aluminum and chromium on the germination and early growth of wheat (Triticum aestivum) varieties Anmol and Kiran
}

\author{
${ }^{1}$ S. N. Jamal, ${ }^{1}$ M. Z. Iqbal and ${ }^{* 2}$ M. Athar \\ ${ }^{1}$ Department of Botany, University of Karachi, Karachi 75270, Pakistan \\ ${ }^{2}$ California Department of Food and Agriculture, Sacramento, USA \\ Received 24 May 2006; revised 2 August 2006; accepted 3 September 2006; available online 1 October 2006
}

\begin{abstract}
A greenhouse experiment was conducted to determine the phytotoxic effect of aluminum and chromium on the germination and early growth of two wheat (Triticum aestivum) varieties Anmol and Kiran. Seed were treated with 40, 80, 120 and $160 \mathrm{ppm}$ of aluminum and chromium solution individually and in combined form. Observations were made on seed germination, root, shoot and seedling length, and dry biomass. Seed germination and dry biomass showed no effect of aluminum, chromium and combined treatment. Root, shoot and seedling length of both the varieties showed significant $(\mathrm{P}<0.05)$ decrease as compared to control. The growth was also reduced as the concentration of aluminum and chromium increased. Seedling length decreased in both the varieties at all the concentration of different treatment of aluminum, chromium and combined treatment. Attempts are being made in different laboratories to construct novel plants using genetic manipulation technologies that may have a greater tolerance to the presence of toxic metals. The results of the present study may help in understanding the mechanisms involved and their possible use in pytoremediation.
\end{abstract}

Key words: Aluminum, chromium, wheat varieties germination, phytotoxicity

\section{INTRODUCTION}

Heavy metal phytotoxicity is considered to be the main factor limiting plant growth, and thus crop cultivation on acid soils (Foy, 1984, 1988). Acid soils comprise large area of the world's agricultural regions, particularly in the tropics and subtropics. Soil acidity is an important factor limiting food production in developing countries (Kochian, 1995). Fox (1979) found that yield of maize was reduced at aluminum saturation of $50 \%$. Excess of aluminum is generally considered to be responsible for inhibiting growth and depressing yields on acid soils. Farina (1980) conducted liming experiment with maize and showed that aluminum toxicity can also be induced by liming reddish brown and ground lateric soils. Aniol (1989) studied the induction of aluminum tolerance in wheat seedling by low doses of aluminum in nutrient solution and found better root elongation. Chromium is considered as a strong toxic element. Chromium ions are tightly bound to humus and clay particles and are more or less insoluble in the soil.

\footnotetext{
*Corresponding author, Email: atariq@cdfa.ca.gov
}

Tel.: +916 651 0267; Fax: +916 6510275
Its availability in plants is therefore generally low but mobility and availability are relatively decreased with the increasing pH. Mengel and Kirkby (1987) mentioned that $0.5 \mathrm{ppm}$ of chromium as chromium sulphate stimulated growth in hydroponic experiment with maize. They found that the growth was inhibited at $5 \mathrm{ppm}$ and strongly inhibited at $50 \mathrm{ppm}$. El-Bassam (1978) reported that low $\mathrm{Cr}^{+3}$ concentrations promote plant growth and also stimulate chlorophyll synthesis and photosynthetic activity. Hexavalent anionic form of chromium is several times as toxic as the trivalent cation $\mathrm{Cr}^{+3}$. Mechanism of resistance in plants continues to remain poorly understood. Such resistance arises either by the ability of the plants to exclude metals from the root or to detoxify metals within the plants (Koachin, 1995; Taylor, 1995). In wheat, malate exudation from root tips seems to be an important mechanism for aluminum detoxification (Delhaize, et al., 1993b). Osawa and Matsumoto (2001) showed that malate efflux started within 5 minutes after the addition of aluminum in wheat. Several economically important cereal grasses such as Hordeum vulgare, 
Triticum aestivum and Zea mays have been particularly useful in such studies (Farina, 1980; MossorPietraszewska, 2001 and Sharma and Mehrota, 1993). A number of studies have been conducted on relative root growth inhibition to define categories of sensitivity and to identify more tolerant cultivars of wheat (Basu, et al., 1994; Delhaize, et al., 1993a, b). Wheat (Triticum asetivum L.) is the staple food for a large part of the world population including Pakistan. Wheat is grown in Pakistan on 8.141 million hectares with an average yield of 2.28 tons per hectare wit a total production of 18535 thousand tons (Agricultural Statistics of Pakistan, 2003, 2004). The average yield is below than most wheat producing countries like Germany (7.9 tons per hectare), France (6.6 tons per hectare) and Egypt and Germany (6.4 tons per hectare). With increasing population, the over-demanding production of wheat can be increased either by bringing more area under wheat cultivation or by introducing high yielding wheat varieties which are resistant against biotic and abiotic environmental stresses. This study constitutes part of a broader research project to focusing on testing the effect of heavy metals on plant growth (Jamal, et al., 2006a, b, c). The present study was carried out to determine the effect of aluminum and chromium individually and in combination on seed germination and seedling growth of two wheat varieties.

\section{MATERIALS AND METHODS}

The seeds of two wheat (Triticum aestivum) variety Anmol and Kiran were obtained from Pakistan Agricultural Research Council, Islamabad. The seeds were surface sterilized with $1.2 \%$ sodium hypochloride solution. Aluminum was applied in the form of aluminum nitrate and chromium was applied in the form of potassium dichromate $\left(\mathrm{K}_{2} \mathrm{Cr}_{2} \mathrm{O}_{7}\right)$ following methods reported elsewhere (Jamal, et al., 2006a, b). Aqueous solutions of both the metals were prepared at concentration of 40, 80,120 and $160 \mathrm{ppm}$. Control was free from these metals. Fifteen seeds of each cultivar of wheat were placed in each petri plates and supplied with $3 \mathrm{~mL}$ aluminum and chromium solution applied individually and in combined form. The petri plates were kept in the dark and observed for germination. The seeds were considered germinated with the emergence of radicles. The germinated seeds were then transferred to day and night length of 10/14 h respectively illuminated with 160 watt light with temperature regime of about $31 \pm 2{ }^{\circ} \mathrm{C}$. The average relative humidity was $75 \%$ as recorded by Sling psychrometer in the laboratory. Root, shoot and seedling length were measured after 10 days, and the seedling weight was recorded after drying in an oven at $80^{\circ} \mathrm{C}$ for $24 \mathrm{~h}$. Data were analyzed statistically by ANOVA and Duncan's multiple range tests (Sokal and Rohlf, 1995).

\section{RESULTS}

Seeds of both the wheat varieties Anmol and Kiran germinated well under all the treatments (Tables 1-6). All the seeds germinated next day. Seed germination of both the varieties was elevated at different concentration as compared to control (Tables 1-6). Control showed $80 \%$ germination and aluminum, chromium and combined treatments showed $90 \%$ germination. Results showed that both the aluminum and chromium metals individually and in combined form significantly $(\mathrm{P}<0.05)$ affected root, shoot and seedling length of both the varieties as compared to control (Tables 1-6). Chromium significantly $(\mathrm{P}<0.05)$ reduced the growth of the seedling than aluminum and combined treatments. Root length of variety Kiran was significantly $(\mathrm{P}<0.05)$ inhibited at all the treatments of aluminum and chromium as compared to control. Combined treatments showed comparatively better effect on root length of Kiran than the individual chromium treatment. Root length of variety Anmol was slightly larger than root length of variety Kiran. Aluminum treatment showed more or less better effect than chromium and combined treatment as compared to control. Shoot length of both the varieties Anmol and Kiran was inhibited by the individual chromium and combined treatments but aluminum treatment enhanced the shoot growth (Tables 1-6). All the treatments showed inhibition in both the varieties as compared to control whereas growth was significantly $(\mathrm{P}<0.05)$ reduced by chromium. However, the combined treatment showed the intermediate effect (Tables 1-6). Seedling length of both the varieties also showed similar inhibitory effect in all the treatments (Tables 1-6). The aluminum treatment showed enhanced and chromium treatment produced reduced growth. Different concentrations showed inhibition as compared to control. The length of the seedlings of both the varieties was decreased with increasing concentration of the metals. The aluminum and chromium treatments did not show any inhibitory or enhanced effect on dry biomass (Tables 1-6). Chromium and combined treatment showed similar effect whereas aluminum showed a little increase in biomass in both the wheat varieties. 
Table 1: Effect of aluminum on germination and growth of Triticum aestivum var. Anmol

\begin{tabular}{lcccccc}
\hline Treatment & Conc. (ppm) & Germination $\%$ & $\begin{array}{c}\text { Root length } \\
(\mathrm{cm})\end{array}$ & $\begin{array}{c}\text { Shoot length } \\
(\mathrm{cm})\end{array}$ & $\begin{array}{c}\text { Seedling length } \\
(\mathrm{cm})\end{array}$ & Dry biomass (mg) \\
\hline Control & 00 & $80 \pm 2 \mathrm{a}$ & $7.64 \pm 2.83 \mathrm{~b}$ & $7.08 \pm 0.62 \mathrm{c}$ & $14.72 \pm 2.57 \mathrm{c}$ & $20.0 \pm 5.8 \mathrm{a}$ \\
& 40 & $93 \pm 6 \mathrm{a}$ & $5.86 \pm 2.02 \mathrm{ab}$ & $5.55 \pm 0.78 \mathrm{~b}$ & $11.41 \pm 2.75 \mathrm{bc}$ & $19.7 \pm 0.2 \mathrm{a}$ \\
Aluminum & 80 & $90 \pm 10 \mathrm{a}$ & $3.15 \pm 0.45 \mathrm{a}$ & $5.62 \pm 0.79 \mathrm{~b}$ & $10.81 \pm 1.80 \mathrm{~b}$ & $20.0 \pm 5.8 \mathrm{a}$ \\
$(\mathrm{Al})$ & 120 & $80 \pm 0 \mathrm{a}$ & $4.26 \pm 0.59 \mathrm{a}$ & $5.77 \pm 0.14 \mathrm{~b}$ & $8.92 \pm 0.58 \mathrm{ab}$ & $50.7 \pm 5.8 \mathrm{~b}$ \\
& 160 & $86 \pm 12 \mathrm{a}$ & $4.26 \pm 0.59 \mathrm{a}$ & $4.26 \pm 0.59 \mathrm{a}$ & $6.94 \pm 0.94 \mathrm{a}$ & $20.0 \pm 5.8 \mathrm{a}$ \\
\hline
\end{tabular}

significantly different at $\mathrm{P}<0.05$ (Duncan's Multiple Range Test).

Table 2: Effect of chromium on germination and growth of Triticum aestivum var. Anmol

\begin{tabular}{|c|c|c|c|c|c|c|}
\hline Treatment & $\begin{array}{l}\text { Conc. } \\
\text { (ppm) }\end{array}$ & $\begin{array}{c}\text { Germination } \\
\%\end{array}$ & $\begin{array}{l}\text { Root length } \\
\text { (cm) }\end{array}$ & $\begin{array}{l}\text { Shoot length } \\
(\mathrm{cm})\end{array}$ & $\begin{array}{l}\text { Seedling length } \\
(\mathrm{cm})\end{array}$ & $\begin{array}{c}\text { Dry biomass } \\
\text { (mg) }\end{array}$ \\
\hline \multirow[t]{2}{*}{ Control } & 00 & $80 \pm 17 a$ & $7.64 \pm 2.83 b$ & $7.08 \pm 0.62 c$ & $14.72 \pm 2.57 \mathrm{c}$ & $20 \pm 5.8 a$ \\
\hline & 40 & $86 \pm 15 a$ & $2.65 \pm 0.29 a$ & $3.08 \pm 1.02 b$ & $5.74 \pm 0.85 b$ & $20 \pm 5.8 \mathrm{a}$ \\
\hline \multirow{3}{*}{$\begin{array}{l}\text { Chromium } \\
\text { (Cr) }\end{array}$} & 80 & $86 \pm 15 a$ & $2.43 \pm 0.40 a$ & $1.43 \pm 0.63 a$ & $3.86 \pm 0.37 \mathrm{ab}$ & $20 \pm 0.0 \mathrm{a}$ \\
\hline & 120 & $86 \pm 12 a$ & $2.18 \pm 0.67 a$ & $1.71 \pm 0.42 \mathrm{a}$ & $4.89 \pm 1.51 \mathrm{ab}$ & $30 \pm 5.8 \mathrm{a}$ \\
\hline & 160 & $83 \pm 6 a$ & $1.97 \pm 0.55 a$ & $1.02 \pm 0.23 a$ & $2.66 \pm 0.31 \mathrm{a}$ & $24 \pm 2.9 \mathrm{a}$ \\
\hline
\end{tabular}

Statistical analysis determined by ANOVA. Mean values followed by the same letters in the same column are not significantly different $\overline{\text { at }} \overline{\mathrm{P}<0.05 \text { (Duncan's }}$ Multiple Range Test).

Table 3: Effect of combined treatment of aluminum and chromium on germination and growth of Triticum aestivum var. Anmol

\begin{tabular}{|c|c|c|c|c|c|c|}
\hline Treatment & $\begin{array}{l}\text { Conc. } \\
\text { (ppm) }\end{array}$ & Germination \% & $\begin{array}{l}\text { Root length } \\
\text { (cm) }\end{array}$ & $\begin{array}{l}\text { Shoot length } \\
\text { (cm) }\end{array}$ & $\begin{array}{l}\text { Seedling } \\
\text { length(cm) }\end{array}$ & $\begin{array}{c}\text { Dry biomass } \\
\text { (mg) }\end{array}$ \\
\hline Control & 00 & $80 \pm 17 a$ & $7.64 \pm 2.83 b$ & $7.08 \pm 0.62 \mathrm{c}$ & $14.72 \pm 2.57 \mathrm{~b}$ & $20.0 \pm 5.8 \mathrm{a}$ \\
\hline \multirow{3}{*}{$\begin{array}{l}\text { Equally } \\
\text { Combined } \\
(\mathrm{Al}+\mathrm{Cr})\end{array}$} & 80 & $96 \pm 6 a$ & $3.11 \pm .0 .68 \mathrm{a}$ & $2.82 \pm 0.43 \mathrm{ab}$ & $5.93 \pm 0.70 \mathrm{a}$ & $26.0 \pm 3.3 a$ \\
\hline & 120 & $73 \pm 12 a$ & $2.1 \pm 0.42 \mathrm{a}$ & $3.4 \pm 0.17 b$ & $5.5 \pm 0.50 \mathrm{a}$ & $23.0 \pm 3.3 a$ \\
\hline & 160 & $76 \pm 23 a$ & $2.21 \pm 0.22 \mathrm{a}$ & $2.37 \pm 0.71 \mathrm{a}$ & $4.59 \pm 0.92 \mathrm{a}$ & $20.0 \pm 0.0 \mathrm{a}$ \\
\hline
\end{tabular}

$\overline{\text { Statistical analysis determined by ANOVA. }} \overline{\text { Mean values followed by the same letters in the same column are not significantly different at } \mathrm{P}<0.05 \text { (Duncan's }}$ Multiple Range Test).

\pm Standard Error

Table 4: Effect of aluminum on germination and growth of Triticum aestivum var. Kiran

\begin{tabular}{|c|c|c|c|c|c|c|}
\hline Treatment & $\begin{array}{l}\text { Conc. } \\
\text { (ppm) }\end{array}$ & $\begin{array}{c}\text { Germination } \\
\%\end{array}$ & Root length (cm) & Shoot length $(\mathrm{cm})$ & $\begin{array}{l}\text { Seedling length } \\
\text { (cm) }\end{array}$ & $\begin{array}{c}\text { Dry biomass } \\
\text { (mg) }\end{array}$ \\
\hline \multirow[t]{2}{*}{ Control } & 00 & $76.6 \pm 15 a$ & $9.45 \pm 1.06 \mathrm{c}$ & $6.87 \pm 0.54 \mathrm{c}$ & $16.56 \pm 1.81 \mathrm{c}$ & $25.0 \pm 0.6 b$ \\
\hline & 40 & $90.0 \pm 17 a$ & $4.65 \pm .0 .80 \mathrm{~b}$ & $6.08 \pm 0.38 b c$ & $10.74 \pm 1.03 b$ & $56.0 \pm 3.2$ \\
\hline \multirow{3}{*}{$\begin{array}{l}\text { Aluminum } \\
\text { (Al) }\end{array}$} & 80 & $86.6 \pm 6 a$ & $2.52 \pm .0 .42 \mathrm{a}$ & $5.22 \pm 0.30 \mathrm{ab}$ & $7.74 \pm 0.22 \mathrm{a}$ & $16.0 \pm 1.2 \mathrm{a}$ \\
\hline & 120 & $86.6 \pm 15 a$ & $2.38 \pm 0.54 \mathrm{a}$ & $5.99 \pm 0.52 b c$ & $8.36 \pm 1.07 a$ & $30.0 \pm 1.2 \mathrm{~b}$ \\
\hline & 160 & $93.3 \pm 11 \mathrm{a}$ & $2.00 \pm 0.21 \mathrm{a}$ & $4.65 \pm 0.91 a$ & $6.56 \pm 0.90 a$ & $19.3 \pm 0.9 \mathrm{a}$ \\
\hline
\end{tabular}

Statistical analysis determined by ANOVA. Mean values followed by the same letters in the same column are not significantly different at $\mathrm{P}<0.05$ (Duncan's Multiple Range Test).

\pm Standard Error 
Table 5: Effects of chromium on germination and growth of Triticum aestivum var. Kiran

\begin{tabular}{|c|c|c|c|c|c|c|}
\hline Treatment & $\begin{array}{l}\text { Conc. } \\
\text { (ppm) }\end{array}$ & $\begin{array}{c}\text { Germination } \\
\%\end{array}$ & $\begin{array}{l}\text { Root length } \\
\text { (cm) }\end{array}$ & $\begin{array}{l}\text { Shoot length } \\
(\mathrm{cm})\end{array}$ & $\begin{array}{l}\text { Seedling length } \\
(\mathrm{cm})\end{array}$ & $\begin{array}{c}\text { Dry biomass } \\
\text { (mg) }\end{array}$ \\
\hline Control & 00 & $76.6 \pm 15.3 a$ & $9.45 \pm 1.06 \mathrm{c}$ & $6.87 \pm 0.54 c$ & $16.56 \pm 1.81 \mathrm{c}$ & $25.0 \pm 0.6 \mathrm{a}$ \\
\hline \multirow{4}{*}{ Chromium (Cr) } & 40 & $90.0 \pm 10.0 \mathrm{a}$ & $3.2 \pm 0.75 b$ & $2.89 \pm 0.87 \mathrm{~b}$ & $6.09 \pm 1.57 \mathrm{~b}$ & $25.3 \pm 2.9 \mathrm{a}$ \\
\hline & 80 & $80.0 \pm 10.0 \mathrm{a}$ & $2.57 \pm 0.71 \mathrm{~b}$ & $3.04 \pm 1.37 \mathrm{~b}$ & $5.62 \pm 1.29 \mathrm{~b}$ & $30.0 \pm 0.0 \mathrm{ab}$ \\
\hline & 120 & $73.3 \pm 5.8 \mathrm{a}$ & $0.98 \pm 0.36 \mathrm{a}$ & $1.15 \pm 0.18 \mathrm{a}$ & $2.13 \pm 0.23 a$ & $30.0 \pm 0.0 \mathrm{ab}$ \\
\hline & 160 & $83.3 \pm 20.8 \mathrm{a}$ & $1.02 \pm 0.28 \mathrm{a}$ & $1.38 \pm 0.30 \mathrm{a}$ & $2.41 \pm 0.39 \mathrm{a}$ & $34.0 \pm 3.1 \mathrm{~b}$ \\
\hline
\end{tabular}

Table 6: Effects of combined treatment of aluminum and chromium on germination and growth of Triticum aestivum var. Kiran

\begin{tabular}{|c|c|c|c|c|c|c|}
\hline Treatment & $\begin{array}{l}\text { Conc. } \\
\text { (ppm) }\end{array}$ & Germination \% & $\begin{array}{l}\text { Root length } \\
\text { (cm) }\end{array}$ & $\begin{array}{l}\text { Shoot length } \\
\text { (cm) }\end{array}$ & $\begin{array}{l}\text { Seedling length } \\
\qquad(\mathrm{cm})\end{array}$ & $\begin{array}{c}\text { Dry biomass } \\
\text { (mg) }\end{array}$ \\
\hline \multirow[t]{2}{*}{ Control } & 00 & $76.6 \pm 15.3 \mathrm{a}$ & $9.45 \pm 1.06 \mathrm{c}$ & $6.87 \pm 0.54 \mathrm{c}$ & $16.56 \pm 1.81 \mathrm{c}$ & $25.0 \pm 0.6 a$ \\
\hline & 40 & $90.0 \pm 0.0 \mathrm{ab}$ & $3.48 \pm 0.69-\mathrm{b}$ & $3.85 \pm 0.39 a b$ & $7.34 \pm 0.60 \mathrm{~b}$ & $25.0 \pm 0.6 a$ \\
\hline Equally & 80 & $83.3 \pm 5.8 \mathrm{ab}$ & $2.94 \pm 0.16 \mathrm{ab}$ & $4.05 \pm 1.37 \mathrm{~b}$ & $6.98 \pm 1.47 \mathrm{ab}$ & $25.0 \pm 0.6 \mathrm{a}$ \\
\hline \multirow[t]{2}{*}{ Combined $(\mathrm{Al}+\mathrm{Cr})$} & 120 & $93.3 \pm 5.8 \mathrm{~b}$ & $3.06 \pm 0.20 \mathrm{ab}$ & $2.88 \pm 0.51 \mathrm{ab}$ & $5.95 \pm 0.71 \mathrm{ab}$ & $30.0 \pm 0.0 \mathrm{ab}$ \\
\hline & 160 & $90.0 \pm 0.0 \mathrm{ab}$ & $2.28 \pm 0.33 a$ & $2.56 \pm 0.46 a$ & $4.85 \pm 0.72 \mathrm{a}$ & $33.0 \pm 3.3 \mathrm{~b}$ \\
\hline
\end{tabular}

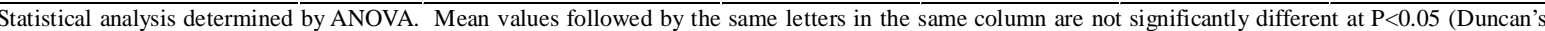
Multiple Range Test).

\pm Standard Error.

\section{DISCUSSION AND CONCLUSION}

Both the wheat varieties Anmol and Kiran showed similar germination response when chromium and aluminum were applied individually and in combined form. The germination of both the varieties was not inhibited by chromium and aluminum treatments. These metals have been reported not to inhibit germination but impair the growth of new roots and seedling establishment (Nosko, et al., 1988 and Rellén-Álvarez, et al., 2006). The growth of both the varieties showed inhibitory effect of chromium and aluminum. Chromium was found more toxic affecting the growth of root, shoot and seedling length than aluminum and combined treatments. Chromium is considered strongly toxic because chromium compound in the soil are more or less insoluble as the metal ions are tightly bound to humus and clay particles. Its availability to the plants is generally low as the mobility is relatively decreased with increasing $\mathrm{pH}$. Mengel and Kirkby (1987) reported that $0.5 \mathrm{ppm}$ of chromium as $\mathrm{Cr}^{+3}$ stimulated growth in hydroponic experiment with maize whereas growth was inhibited at $5 \mathrm{ppm}$ and strongly affected at $50 \mathrm{ppm}$. ElBassam (1987) observed that low chromium concentration promote plant growth and also stimulate chlorophyll synthesis and photosynthetic activity. Hexavalent ionic form of chromium was as toxic as trivalent cation $\mathrm{Cr}^{+3}$. Aluminum also showed inhibitory effect as compared to control but overall enhanced the growth than chromium and combined treatments. Root stunning is a consequence of aluminum induced inhibition of root elongation. Roots became stubby and brittle and root tips and lateral roots became thick and turned brown. Such roots are in efficient in absorbing nutrients and water affecting the growth of shoot than the root. Similar observations were made by Chang, et al. (1999) made similar observations for tobacco treated with a combination of aluminum and iron. Mechanism of resistance in plants continues to remain poorly understood. Such resistance arises either by the plant ability to exclude heavy metals in roots or its ability to detoxify heavy metals within the plants (Hall, 2000; Kochian, 1995; Rellén-Álvarez, et al., 2006 and Taylor, 1995). Detoxification also depends upon organic compounds present in soil and inside plants. Wheat plants are very sensitive to these heavy metals as they have very little external ability to detoxify the toxic metals. Wheat seeds were germinated in the petri plates which were devoid of other minerals. The metals applied did not get detoxified and were absorbed by plants which resulted in the inhibition of root, shoot and seedling length. Osawa and Matsumoto (2001) found that in wheat malate efflux started 5 min after the 
addition of aluminum in wheat. Ma, et al. (1997) observed that in buckwheat, the secretion of oxalic acid occurred within $30 \mathrm{~min}$ after the exposure to aluminum. Organic acid extracted from roots has different ability to precipitate aluminum and reduced toxicity. In wheat and maize, aluminum activated anion channels in the plasma membrane mediate the transport of organic acid anions out of the root cells. Plants have evolved several mechanisms to prevent the toxic action of metals. These include reduction of uptake into the root cells by changes in the kinetic properties of transporters and exudation of complexing agents into the rhizosphere (Watanabe and Osaki, 2002). Once metals have entered the plant they induce the synthesis of the glutathione containing peptides phytochelatins and high cysteine containing proteins, the metallothioneins, which are able to bind the metal ions (Cobbet and Goldsbrough, 2002; Hall, 2002; Quartacci, et al., 2000 and Voskaoboinik, et al., 2002). Ultimately the metals are stored in the vacuole in a relatively non-toxic form (William, et al., 2000). There have been a number of attempts by different laboratories to construct novel plants using genetic manipulation technologies that may have a greater tolerance to the presence of toxic metals (Belouchi, et al., 1997; Macnair, et al., 2000; Sasaki, et al., 2004 and Vitorello, et al., 2005). These plants are currently under intensive study to establish the mechanisms involved and for their possible use in pytoremediation.

\section{ACKNOWLEDGMENT}

The research was funded by a grant from the Faculty of Science, University of Karachi, which is gratefully acknowledged. Special gratitude is expressed to the scientists of Plant Genetic Resources, and National Wheat Program of Pakistan Agricultural Research Council, Islamabad for supplying the seeds of wheat varieties Anmol and Kiran.

\section{REFERENCES}

Agricultural Statistics of Pakistan, (2003-2004). Government of Pakistan. Ministry of Food, Agricultural and Livestocks (Economic Wing), Islamabad, Pakistan.

Aniol, A., (1984). Induction of aluminium tolerance in wheat seedlings by low doses of aluminium in the nutrient solution. Plant Physiol., 75, 551-555.

Basu, U., Basu, A. and Taylor, G. J., (1994). Differential exudation of polypeptides by roots of aluminum-resistant and aluminum-sensitive cultivars of Triticum aestivum L. in response to aluminum stress. Plant Physiol., 106, 151-158. Belouchi A., Kwan T. and Gros, P., (1997). Cloning and characterization of the OsNramp family from Oryza sativa, a new family of membrane proteins possibily implicated in the transport of metal ions. Plant Mol. Biol., 33, 10851092.

Chang, Y. C., Yamamoto, Y. and Matsumoto, H., (1999). Accumulation of aluminium in the cell wall pectin in cultured tobacco (Nicotiana tabacum L.) cells treated with a combination of aluminium and iron. Plant Cell Envirn., 22, 1009-1017.

Cobbet, C. and Goldsbrough P., (2002). Phytochelatins and metallothioneins: roles in heavy metal detoxification and homeostasis. Annu. Rev. Plant Biol., 53,159-182.

Delhaize, E., Craig, S., Beaton, C. D., Bennet, R. J., Jagadish, V. C. and Randall, P. J., (1993). Aluminium tolerance in wheat. Uptake and distribution of aluminium in root apices. Plant. Physiol., 103, 685-693.

Delhaize, E., Ryan, P. R. and Randall, P. J., (1993). Aluminium tolerance in wheat (Triticum aestivum L.). II. Aluminiumstimulated excretion of malic acid from root apices. Plant Physiol., 103, 695-702.

El-Bassam, N., (1978). Spurendemente: Nahrstoffe und Gift Zugleich. Kali-Briefe, 14, 255-272.

Farina (1980). Aluminium toxicity in corn at near neutral soil pH levels. J. Plant Nutr., 2, 683-697.

Fox, R. H., (1979). Soil pH, aluminium saturation and corn grain yield. Soil Sci.,127, 330-334.

Foy, C. D., (1984). Physiological effects of hydrogen, aluminium, and manganese toxicities in acid soil. In: Soil acidity and liming, Amerisan Society of Agronomy, 19, 57-97.

Foy, C. D., (1988). Plant adaptation to acid, aluminium-toxic soils. Comm. Soil Sci. Plant Anal., 19, 959-987.

Hall, J. L., (2000). Cellular mechanisms for heavy metals detoxification and tolerance. J. Exp. Bot., 53, 1-11.

Jamal, S. N., Iqbal, M. Z. and Athar, M., (2006-a). Effect of aluminum and chromium on the germination and growth of two Vigna species. Int. J. Environ. Sci. Technol., 3, 53-58.

Jamal, S. N., Iqbal, M. Z. and Athar, M., (2006-b). Effect of aluminum and chromium on the growth and germination of mesquite (Prosopis juliflora (Swartz.) DC). Int. J. Environ. Sci. Technol., 3, 173-176.

Jamal, S. N., Iqbal, M. Z. and Athar, M., (2006-c). Evaluation of two wheat varieties for phytotoxic effect of mercury on seed germination and seedling growth. Agric. Consp. Sci., Accepted for Publication.

Kochian, L. V., (1995). Cellular mechanism of aluminium toxicity and resistance in plants. Annu. Rev.Plant Physiol. Plant Mole. Biol., 46, 237-260.

Ma, J. F., Zheng, S. J., Matsumoto, H. and Hiradate, S., (1997). Detoxifying aluminum with buckwheat. Nature, 390, 569570.

Macnair M. R., Tilstone G. H. and Smith G. E., (2000). The genetics of metal tolerance and accumulation in higher plants. In: Phytoremediation of contaminated soils and water, eds. Terry N. and Banuelos G., CRC Press, New York, 235-250.

Mengel, K. and Kirkby, E. A., (1987). Principles of plant nutrition. Publ. Int. Potash. Inst., Bern.

Mossor-Pietraszewska, T., (2001). Effect of aluminium on plant metabolism. Acta. Biochim. Polonica., 48, 673-686.

Nosko, P., Brassard, P., Kramer, J. R. and Kershaw K. A., (1988). The effect of aluminum on seed germination and 
early seedling establishment, growth and respiration of white spruce (Picea glauca). Can. J. Bot., 66, 2305-2310.

Osawa, H. and Matsumoto, H., (2001). Possible involvement of protein phosphorylation in aluminum responsive malate efflux from wheat root apex. Plant Physiol., 126, 411-420.

Quartacci M. F., Pinzino C., Sgherri C. L. M., Dalla Vecchia F. and Navari-Izzo F., (2000). Growth in excess copper induced changes in the lipid composition and fluidity of PSII-enriched membranes in wheat. Physiol. Plant., 108, 87-93.

Rellén-Álvarez, R. Ortega-Villasante, C., Álvarez-Fernández, A., del Campo, F. F. and Hernández, L. E., (2006). Stress response of Zea mays to cadmium and mercury. Plant Soil, 279, 41-50.

Sasaki, T., Yamamoto, Y., Ezaki, B., Katsuhara, M., Ahn, S. J., Ryan, P. R., Delhaize, E. and Matsumoto, H., (2004). A wheat gene encoding an aluminum-activated malate transporter. Plant J., 37, 645-653.

Sharma, D. C. and Mehrota and S. C., (1993). Chromium toxicity effects on wheat (Triticum aestivum L. cv. HD 2204). Indian J. Environ. Health, 35, 330-332.
Sokal, R. R. and Rohlf, F. J., (1995). Biometry. W. H. Freeman and Co., NewYork.

Taylor, G. J., (1995). Overcoming barriers to understanding the cellular basis of aluminum resistance. Plant Soil, 171, 89-103.

Vitorello, V. A., Capaldi, F. R. and Stefanuto, V. A., (2005). Recent advances in aluminum toxicity and resistance in higher plants. Braz. J. Plant Physiol., 17, 129-143.

Voskaoboinik, I., Camakaris, J.and Mercer, J. F. B., (2002). Understanding the mechanism and function of copper Ptype ATPases. Adv. Protein Chem., 60, 123-150.

Watanabe, T. and Osaki M., (2002). Mechanisms of adaptation to high aluminum condition in native plant species growing in acid soils: A review. Commun. Soil Sci. Plant. Anal., 33, 1247-1260.

Williams, L. E., Pitman, J. K. and Hall, J. L., (2000). Emerging mechanisms for heavy metal transport in plants. Biochem. Biophys. Acta.,1465, 104-126.

\section{AUTHOR (S) BIOSKETCHES}

Jamal, S. N., B.Sc. (Hons.), M.Sc., is a lecturer in the Department of Botany, City College Karachi and a Ph.D. research fellow in the Department of Botany, University of Karachi, Karachi, Pakistan. E-mail:shagi83@hotmail.com

Iqbal, M. Z., B.Sc. (Hons.), M.Sc., Ph.D. is professor and chairman, Department of Botany, University of Karachi, Karachi, Pakistan. E-mail: mziqbalbotuokpk@yahoo.com

Athar, M., M.Sc., M.Phil., Ph.D., D.Sc. is a research scientist with California Department of Food and Agriculture, Sacramento, California, USA. E-mail: atariq@cdfa.ca.gov

\section{This article should be referenced as follows:}

Jamal, S. N., Iqbal, M. Z., Athar, M., (2006). Phytotoxic effect of aluminum and chromium on the germination and early growth of wheat (Triticum aestivum) varieties Anmol and Kiran Int. J. Environ. Sci. Tech., 3 (3), 411-416 